\title{
Guidance for Ship Operators for the Protection of the Health of Seafarers to limit the Spread of Coronavirus (COVID-19) Outbreak by ICS
}

\author{
Mohammad Danil Arifin ${ }^{1}$ \\ ${ }^{1}$ Department of Marine Engineering, Faculty of Ocean Technology \\ Darma Persada University, Jakarta \\ E-mail: \\ danilarifin.mohammad@gmail.com \\ mohammad_danil_arifin@ftk.unsada.ac.id
}

\begin{abstract}
COVID-19, more commonly known as the coronavirus, has developed into a pandemic. In order for maritime shipping to continue its operations, shipping companies should undertake measures to protect their members of crew and passengers. In the new guidance document "Coronavirus (COVID-19) - Guidance for Ship Operators for the Protection of the Health of Seafarers", the International Chamber of Shipping ICS explains the right protection measures for the novel coronavirus and how to react if a case of illness or a suspect case occurs on board. The purpose is to help shipping companies follow advice provided by United Nations agencies including the World Health Organization (WHO), the International Maritime Organization (IMO) and the International Labour Organization (ILO), as well as the European Centre for Disease Prevention and Control (ECDC). In the guidance document, it is explained how seafarers should generally protect themselves preventatively, especially with hygienic preventative measures such as regular hand washing and the right conduct when coughing and sneezing (i.e. with a tissue or in the crook of the arm). ICS published posters that can be put up by ship operators on board their ships for information purposes. They are free for download on the ICS website and can be found in Annex A of the Guidance. The crew should be informed about how to deal with suspect and confirmed cases. A ship-specific outbreak management plan should be developed for concrete guidance of the crew.
\end{abstract}

Keywords: Ship Operators, Seafarers, Coronavirus (COVID-19), ICS, IMO, WHO, ILO, ECDC 


\section{Introduction}

COVID-19 - a virus which can lead to respiratory disease and pneumonia - was first reported in December 2019 in Wuhan, China. More than 90,000 cases have been reported at the time of going to print, including several thousand deaths. While most of these have been concentrated in China, the virus now appears to be spreading globally. No vaccine is currently available, and the focus of health authorities worldwide has been containment of the virus through preventative measures to limit and slow down widespread transmission.

The WHO has declared the outbreak a Public Health Emergency of International Concern under the WHO International Health Regulations (IHR). This severe public health challenge requires close co-operation between governments and shipping companies engaged in maritime trade, in order to protect the health of seafarers (and passengers) as well as the general public.

On 5 March 2020, the International Chamber of Shipping (ICS) issued this brand new guidance for the global shipping industry to help combat the spread of the coronavirus (COVID19). The document contains advice on managing port entry restrictions and offers practical protective measures against COVID-19 for seafarers, including an Outbreak Management Plan.

Information around important topics is provided, including port entry restrictions, preboarding screening, education and what to do in suspected cases of infection. There is also straightforward advice on hygiene measures for seafarers on ships, managing high risk exposure, case handling, isolation and cleaning, disinfection and waste management. The guidance also comes with posters which can be printed out and placed on board ships, as well as a Sample PreBoarding Passenger Locator Form and a WHO COVID-19 Support and Logistics Supplies List.

The Guidance identifies three groups in relation to containing the outbreak potential: confirmed cases, suspect cases and people who have been in close contact to confirmed or suspect cases. Any suspect case has to be reported by the master to the next port of call. The virus has to be verified by a laboratory. The subsequent measures are given in the Guidance. 


\section{Discussion}

This guidance has been designed to support all types of ships which operate in international waters to limit the spread of the Coronavirus. Issued by the International Chamber of Shipping (ICS) and launched at the International Maritime Organization (IMO), the guidance document aims to protect the health of seafarers and limit the spread of the virus.

The position taken echoes that of the World Health Organization (WHO) and many national governments, stressing the importance of hand and respiratory hygiene. The document advises:

- $\quad$ frequent hand washing by crew (and passengers) using soap and hot water or alcoholbased (at least 65-70\%) hand rub for 20 seconds

- $\quad$ avoidance of touching the face including mouth, nose and eyes with unwashed hands (in case hands have touched surfaces contaminated with the virus)

- $\quad$ seafarers (and passengers) should be encouraged to cover their nose and mouth with a disposable tissue when sneezing, coughing, wiping and blowing the nose then dispose of the used tissue immediately

- If a tissue is not available, crew should cover their nose and mouth and cough or sneeze into a flexed elbow

- $\quad$ all used tissues should be disposed of promptly into a waste bin

- $\quad$ seafarers should aim to keep at least one metre (3 feet) distance from other people, particularly those that cough or sneeze or may have a fever. If they are too close, other crew members can potentially breathe in the virus

- $\quad$ meat, milk or animal products should always be handled with care, to avoid crosscontamination with uncooked foods, consistent with good food safety practices

Face masks are deemed to be of some use, but only in limited circumstances. The guidance also covers issues such as: port entry restrictions; pre-boarding information and screening; management of suspected cases of infection; cleaning, disinfection and waste management. ICS also published posters that can be put up by ship operators on board their ships for information purposes. 
At the end of the document are information posters for crew and passengers, a sample preboarding passenger locator form, and a copy of the WHO COVID-19 support and logistics supplies list. The Coronavirus (COVID-19)- Guidance for Ship Operators for the Protection of the Health of Seafarers can be freely downloaded at:

1. https://www.ics-shipping.org/docs/default-source/resources/coronavirus-(covid-19)guidance-for-ship-operators-for-the-protection-of-the-health-ofseafarers.pdf?sfvrsn $=6$

2. https://www.seafarerswelfare.org/assets/documents/resources/Coronavirus-COVID19-Guidance-for-Ship-Operators-for-the-Protection-of-the-Health-of-Seafarers.pdf 


\section{APPENDIX}

Coronavirus (COVID-19)- Guidance for Ship Operators for the Protection of the Health of Seafarers 


\section{Coronavirus (COVID-19)}

Guidance for Ship Operators for the Protection of the Health of Seafarers

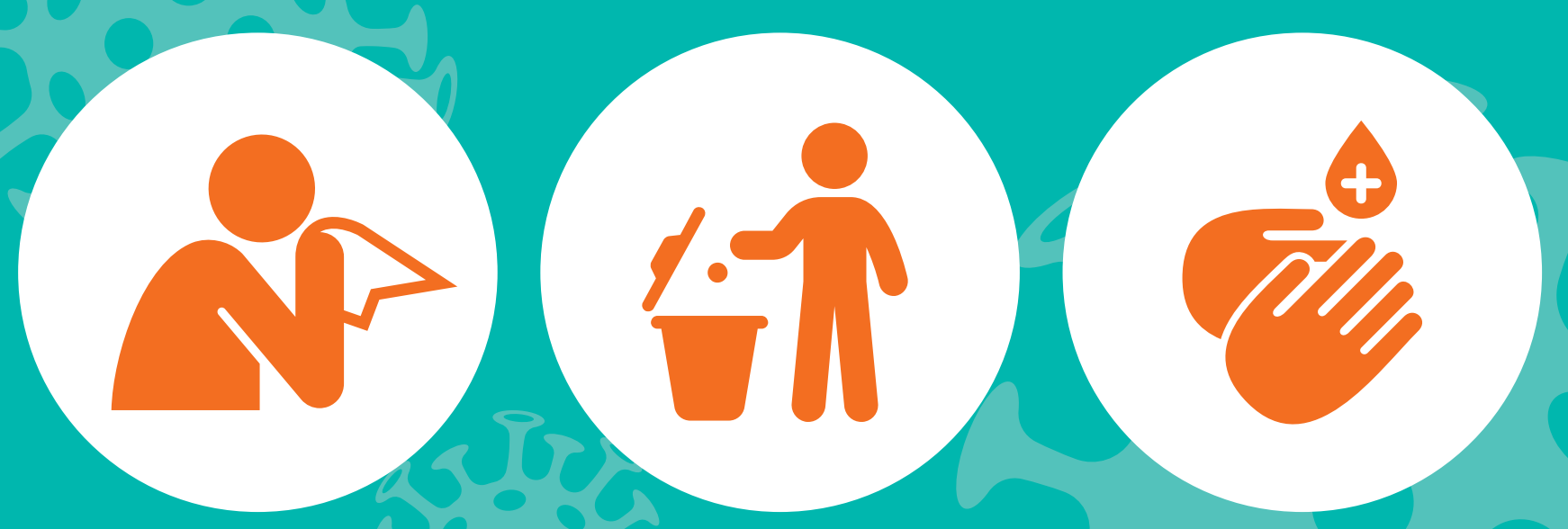

Version 1.0 - 3 March 2020 


\title{
Coronavirus (COVID-19) \\ Guidance for Ship Operators for the Protection of the Health of Seafarers
}

\author{
Published by \\ Marisec Publications \\ 38 St Mary Axe \\ London EC3A 8BH
}

Version 1.0 - 3 March 2020

Tel: +442070901460

Email: publications@marisec.org

Web: www.ios-shipping.org

() Marisec Publications 2020

While the advice given in this Guidance has been developed using the best information available, it is intended purely as guidance to be used at the user's own risk. No responsibility is accepted by Marisec Publications or by the International Chamber of Shipping or by any person, firm, corporation or organisation who or which has been in any way concerned with the furnishing of information or data, the compilation, publication or any translation, supply or sale of this Guidance for the accuracy of any information or advice given herein or for any omission herefrom or from any consequences whatsoever resulting directly or indirectly from compliance with or adoption of guidance contained therein even if caused by a failure to exercise reasonable care.

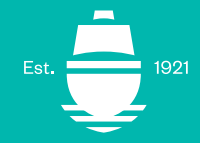

The International Chamber of Shipping (ICS) is the global trade association representing national shipowners' associations from Asia, the Americas and Europe and more than $80 \%$ of the world merchant fleet.

Established in 1921, ICS is concerned with all aspects of maritime affairs particularly maritime safety, environmental protection, maritime law and employment affairs.

ICS enjoys consultative status with the UN International Maritime Organization (IMO). 


\section{Coronavirus (COVID-19) \\ Guidance for Ship Operators for the Protection of the Health of Seafarers}


Guidance for Ship Operators for the Protection of the Health of Seafarers

\section{Contents}

1 Introduction 5

2 Port Entry Restrictions 6

3 Protective Measures Against COVID-19 for Seafarers 7

4 Outbreak Management Plan for COVID-19 8

5 Pre-Boarding Information 8

6 Pre-boarding Screening 8

7 Information and Awareness $\quad 8$

8 Suspected Cases of Infection 9

9 Close Contacts (High Risk Exposure) 10

10 Hygiene Measures for Seafarers on Ships 10

11 Management of Suspect Cases by Medical Support Providers 11

12 Precautions at the Ship Medical Facility 11

13 Laboratory Testing 11

14 Case Handling 12

15 Isolation 12

16 Reporting to the Next Port of Call 13

17 Disembarkation of a Suspect and a Confirmed Case 13

18 Cleaning, Disinfection and Waste Management 14

19 Management of Contacts of a Suspect Case 14

20 Supplies and Equipment 15

$\begin{array}{ll}\text { Annex A - Posters } & 17\end{array}$

Annex B - Sample Pre-Boarding Passenger Locator Form (PLF) 21

Annex C - WHO COVID-19 Support and Logistics Supplies List, with availability advice provided by IMHA 
Guidance for Ship Operators for the Protection of the Health of Seafarers

\section{Introduction}

In response to the current coronavirus (COVID-19) outbreak, this Guidance has been produced by the International Chamber of Shipping (ICS) to support all types of ships which operate in international waters. The purpose is to help shipping companies follow advice provided by United Nations agencies including the World Health Organization (WHO), the International Maritime Organization (IMO) and the International Labour Organization (ILO), as well as the European Centre for Disease Prevention and Control (ECDC).

COVID-19 - a virus which can lead to respiratory disease and pneumonia - was first reported in December 2019 in Wuhan, China. More than 90,000 cases have been reported at the time of going to print, including several thousand deaths. While most of these have been concentrated in China, the virus now appears to be spreading globally. No vaccine is currently available, and the focus of health authorities worldwide has been containment of the virus through preventative measures to limit and slow down widespread transmission.

The WHO has declared the outbreak a Public Health Emergency of International Concern under the WHO International Health Regulations (IHR).

This severe public health challenge requires close co-operation between governments and shipping companies engaged in maritime trade, in order to protect the health of seafarers (and passengers) as well as the general public.

ICS is grateful for the support of the following organisations in preparing this Guidance: IMO, ILO, WHO, International Maritime Health Association (IMHA), European Centre for Disease Prevention and Control (ECDC), Mediterranean Shipping Company S.A. (MSC) and Wilhelmsen Ships Service. 


\section{Port Entry Restrictions}

WHO, as at 3rd March 2020, has not currently recommended any international travel or trade restrictions, and according to the IHR (and other international regulations) ships shall not be refused 'free pratique' by the IHR state parties for public health reasons, i.e. permission to enter a port, embark or disembark discharge or load cargo or stores. The IHR states Parties may subject granting free pratique to inspection, and, if a source of infection or contamination is found on board, conduct necessary, disinfection, decontamination, disinsection or deratting, or other measures necessary to prevent spread of the infection or contamination.

The WHO IHR can be available at www.who.int/ihr/publications/9789241580496/en/

Nevertheless, many governments have now introduced national and local restrictions including:

- Delayed port clearance;

- Prevention of crew or passengers from embarking or disembarking (preventing shore leave and crew changes);

- Prevention of discharging or loading cargo or stores, or taking on fuel, water, food and supplies; and

- Imposition of quarantine or refusal of port entry to ships (in extreme cases).

While such measures can severely disrupt maritime traffic - and may well be in breach of the IHR, the Convention on Facilitation of International Maritime Traffic (FAL Convention) and other maritime principles regarding the rights and treatment of seafarers and passengers - the reality is that shipping companies may have little choice but to adhere to these national and local restrictions due to the serious concern about COVID-19 and the potential risk to public health.

However, it is very important for port States to accept all ships (both cargo and passenger), for docking and to disembark suspected cases on board, as it is difficult to treat suspect cases on board and it could endanger others.

If any infection or contamination is found on board visiting ships, port States may take additional measures to prevent spread of the infection or contamination.

Together with flag States, companies and Masters should co-operate with port State authorities to ensure, where appropriate, that:

- Seafarers can be changed;

- Passengers can embark and disembark;

- Shore leave can continue if safe to do so;

- Cargo operations can occur;

- Ships can enter and depart shipyards for repair and survey;

- Stores and supplies can be loaded; and

- Necessary certificates and documentation can be issued.

ILO has advised that during the evolving COVID-19 outbreak, effective protection of the health and safety of seafarers must remain a priority. Under the ILO Maritime Labour Convention (MLC), flag States must ensure all seafarers on ships flying their flag are covered by adequate measures to protect their health and that they have access to prompt and adequate medical care while working on board.

Port States must ensure that any seafarers on board ships in their territory who need immediate medical care are given access to medical facilities on shore.

Wilhelmsen Ships Service has developed an interactive map on current port restrictions which is available at https://willhelmsen.com/ships-agency/campaigns/coronavirus/coronavirus-map 


\section{Protective Measures Against COVID-19 for Seafarers}

Human-to-human transmission of COVID-19 is understood to occur primarily through droplets from a person with COVID-19, e.g. from coughing and sneezing, landing on objects and surfaces around the person. Other people then catch COVID-19 by touching these objects or surfaces, then touching their eyes, nose or mouth. People can also catch COVID-19 if they breathe in droplets from a person with COVID-19 who coughs, sneezes or breathes out droplets.

Seafarers (on board ship or on leave) should inform their healthcare providers if they have visited an area where COVID-19 has been reported within the past 14 days, or if they have been in close contact with someone with respiratory symptoms who has been to a place which has COVID-19.

If seafarers have fever, cough or difficulty breathing it is important to seek medical attention promptly.

When someone infected with a respiratory disease, such as COVID-19, coughs or sneezes they project small droplets containing the virus. Sneezing or coughing into hands may contaminate objects, surfaces or people that are touched. Standard Infection Protection and Control (IPC) precautions emphasise the vital importance of hand and respiratory hygiene. In particular:

- Frequent hand washing by crew (and passengers) using soap and hot water or alcohol-based (at least $65-70 \%$ ) hand rub for 20 seconds;

- Avoidance of touching the face including mouth, nose and eyes with unwashed hands (in case hands have touched surfaces contaminated with the virus);

- Seafarers (and passengers) should be encouraged to cover their nose and mouth with a disposable tissue when sneezing, coughing, wiping and blowing the nose then dispose of the used tissue immediately;

- If a tissue is not available, crew should cover their nose and mouth and cough or sneeze into a flexed elbow;

- All used tissues should be disposed of promptly into a waste bin;

- Seafarers should aim to keep at least one metre ( 3 feet) distance from other people, particularly those that cough or sneeze or may have a fever. If they are too close, other crew members can potentially breathe in the virus; and

- Meat, milk or animal products should always be handled with care, to avoid cross-contamination with uncooked foods, consistent with good food safety practices.

It is important that seafarers should be given the time and opportunity to clean their hands after coughing, sneezing, using tissues, or after possible contact with respiratory secretions or objects or surfaces that might be contaminated.

Although face masks may provide some protection - especially if there is a risk of exposure when interacting with persons from outside the ship - the routine use of face masks is not generally recommended as protection against COVID-19. WHO advises that it is appropriate to use a mask when coughing or sneezing. If an individual is healthy, it is only necessary to wear a mask if the person is taking care of a person with the suspected COVID-19 infection.

www.who.int/emergencies/diseases/novel-coronavirus-2019/advice-for-public/when-and-how-to-use-masks

\section{Hand and respiratory hygiene are considered far more important.}

Safety posters for ships are provided in Annex A. 


\section{Outbreak Management Plan for COVID-19}

Ships should develop a written outbreak management plan. Seafarers on board should have knowledge of the outbreak management plan and implement it as required.

Passengers and Seafarers should receive information in accordance with the WHO advice for international traffic regarding the outbreak of COVID-19.

Advice is available on the WHO website for COVID-19 at www.who.int/health-topics/coronavirus

\section{Pre-Boarding Information}

This Guidance uses information contained in the WHO Operational considerations for managing COVID-19 cases/outbreak on board ships, interim guidance 24 February 2020. It is also recommended to use this alongside the WHO Handbook for Management of Public Health Events on Board Ships.

www.who.int/publications-detail/operational-considerations-for-managing-covid-19-cases-outbreak-onboard-ships

\section{Pre-boarding Screening}

Until the end of the COVID-19 outbreak, all ships are advised to provide passengers and seafarers with general information on COVID-19 and its preventative measures and implement pre-boarding screening.

A sample pre-boarding Passenger Locator Form (PLF) is provided in Annex B. The purpose is to identify passengers who may need to have their boarding deferred or rescheduled and to ensure proper management by competent health authorities.

\section{Information and Awareness}

Ship Operators should provide guidance to crew on how to recognise the signs and symptoms of COVID-19. Crew should be reminded of the plan and procedures to follow if a passenger or crew member on board displays signs and symptoms of acute respiratory disease.

Country-specific guidance about prevention measures may be available, such as at www.colc.gov/quarantine/maritime/recommendations-for-ships.html

Medical staff on board ships should be informed and updated about the outbreak of COVID-19 and any new evidence and guidance available. It is recommended to review the WHO website for COVID-19. Information about the use of medical masks can also be found on the website.

The posters provided at Annex A can also be used onboard to provide a gentle reminder of best practices for seafarers to adopt. They are also available for download from the ICS website at

www.ics-shipping.org/free-resources 


\section{Suspected Cases of Infection}

If people only have mild respiratory symptoms and have not visited an area where COVID-19 has been reported within the past 14 days, or if they have been in close contact with someone with respiratory symptoms who has been to a place which has COVID-19, they should still carefully practise basic hand and respiratory hygiene and isolate themselves, if possible, until fit.

If the virus spreads more widely this definition may change, but a suspect case requiring diagnostic testing is generally considered to be:

A patient with acute respiratory illness (fever and at least one sign/symptom of respiratory disease (e.g. cough, shortness of breath), and with no other set of causes that fully explains the clinical presentation and a history of travel to or residence in a country/ area or territory reporting local transmission of (COVID-19) during the 14 days prior to the onset of the symptoms.

\section{Or}

A patient with any acute respiratory illness and having been in contact with a confirmed or suspected COVID-19 case during the 14 days prior to the onset of the symptoms.

\section{Or}

A patient with severe acute respiratory infection (fever and at least one sign/symptom of respiratory disease e.g. cough, shortness of breath and requiring hospitalization and with no other set of causes that fully explain the symptoms.

Any person on board that may have been in close contact with a suspect case should be:

- Traced immediately after the suspect case is identified;

- Asked to remain on board until laboratory results of the suspect case are available (measures that apply following positive laboratory results are described below); and

- Categorised as either contacts with high risk exposure or with low risk exposure.

Further guidance can be found at www.who.int/publications-detail/global-surveillance-for-human-infection-with-novel-coronavirus-(2019-ncov)

All persons on board that fulfil the definition of a 'close contact' (see below) should be asked to complete a PLF (see Annex B) and remain on board the ship in their cabins or preferably at a specially designated facility ashore (if feasible and in case that the ship is at the turnaround port where embarking/disembarking passengers or discharging/loading cargos/stores takes place), in accordance with instructions received by the competent health authorities, until the laboratory result for the suspect case is available. Persons on board who do not fulfil the definition of a 'close contact' will be considered as having low risk exposure and should:

- Be requested to complete PLFs with their contact details and the locations where they will be staying for the following 14 days;

- Be provided with the following information and advice on the details of symptoms and how the disease can be transmitted;

- Be asked to self-monitor for COVID-19 symptoms, including fever of any grade, cough or difficulty breathing, for 14 days from their last exposure; and

- Be asked to immediately self-isolate and contact health services in the event of any symptom appearing within 14 days. If no symptoms appear within 14 days of their last exposure, the contact person is no longer considered likely to develop COVID-19. 


\section{Close Contacts (High Risk Exposure)}

A 'close contact' is a person who, for example:

- Has stayed in the same cabin with a suspect/confirmed COVID-19 case;

- Has had close contact within one metre or was in a closed environment with a suspect/confirmed COVID-19 case (for passengers this may include sharing a cabin);

- Participated in common activities on board or ashore;

- Participated in the same immediate travelling group;

- Dined at the same table (for crew members this may include working together in the same ship area);

- Is a cabin steward who cleaned the cabin;

- Is restaurant staff who delivered food to the cabin;

- Is a gym trainer who provided close instruction to a case; or

- Is a medical support worker or other person providing direct care for a COVID-19 suspect or confirmed case.

Close contacts may be difficult to define on board a confined space such as a passenger ship, and if widespread transmission is identified then all persons on board could be considered as 'close contacts' having had high risk exposure.

\section{Hygiene Measures for Seafarers on Ships}

Ship operators should provide specific guidance and training for their seafarers regarding:

- Hand washing (using soap and hot water, rubbing hands for at least 20 seconds; one way to know how long 20 seconds is would be to silently sing "happy birthday to you!" twice);

- When hand washing is essential (e.g. after assisting an ill traveller or after contact with surfaces they may have contaminated, etc);

- When to hand rub with an antiseptic instead of hand washing, and how to do this;

- How to cough and sneeze hygienically (e.g. using disposable tissues or a flexed elbow);

- Appropriate waste disposal;

- When and how to use masks; and

- Avoiding close contact with people suffering from acute respiratory infections. 


\section{Management of Suspect Cases by Medical Support Providers}

If someone on board is suspected to have COVID-19, Personal Protective Equipment (PPE) for interview and assessment may be used by medical support providers.

Key outbreak control activities will include supportive treatment, e.g. giving oxygen, antibiotics, hydration and fever/pain relief.

\section{Precautions at the Ship Medical Facility}

The following precautions should be taken:

- Patients must cover their nose and mouth with a tissue when coughing or sneezing; or a flexed elbow if not wearing a mask. This should be followed by performing hand hygiene with an alcohol-based hand rub (at least $65-70 \%$ ) or soap and hot water for 20 seconds.

- Careful hand washing should occur after contact with respiratory secretions.

- Suspect cases must wear a medical mask once identified and evaluated in a private room with the door closed, ideally an isolation room;

- Any person, including healthcare workers, entering the room should apply appropriate precautions in accordance with the requirements of WHO infection prevention and control during healthcare when COVID-19 is suspected; and

- After preliminary medical examination, if the ship's medical officer or person responsible for the provision of medical care believes a suspect case exists, the patient should be isolated.

If the illness is not considered a suspect case but the person has respiratory symptoms, the person should still not return to any places where they will be in contact with others onboard either seafarers or passengers..

\section{Laboratory Testing}

Laboratory examination of clinical specimens for suspect cases should be made with the competent authorities at the port who will then inform the ship's officers about test results. 


\section{Case Handling}

Case handling should:

- Be initiated by the ship's medical care providers in order to detect any new suspect cases;

- Include directly contacting crew and passengers, asking about current and recent illnesses, and checking if any person meets the criteria for a suspect case; and

- Be recorded in the appropriate medical log book.

Medical care providers should:

- Ensure a suspect case is interviewed and provide information about the places they have visited within the last 14 days prior to the onset of symptoms and their contacts, including the period from one day before the onset of symptoms on board the ship or ashore; and

- Keep records regarding:

- Anyone on board who has visited the medical facility as a suspect case and the isolation and hygiene measures taken;

- Any close contact or casual contact with low risk exposure to monitor their health;

- Contact details of casual contacts with low risk exposure who will disembark and the locations where they will be staying in the next 14 days (completed PLFs or Maritime Declarations of Health (MDHs); and

- Results of active surveillance.

\section{Isolation}

Isolate suspect cases on board immediately and inform the next port of call of suspect cases:

- With acute respiratory infection, either a cough, sore throat, shortness of breath, whether requiring hospitalisation or not;

- Who in the 14 days before onset of symptoms met the definition of a suspect case as outlined in sections 8 and 9 .

Patients should be isolated in either an isolation ward, cabin, room or quarters with precautionary measures. Anyone entering an isolation room should wear gloves, impermeable gowns, goggles and medical masks. 


\section{Reporting to the Next Port of Call}

The competent authority of the next port of call must always be informed if there is a suspect case on board.

For ships on an international voyage, if someone has died on board the International Health Regulations (IHR) state that the MDH should be completed and sent to the competent authority in accordance with local requirements.

The Master should immediately alert the competent authority at the next port of call about any suspect case to determine if the necessary capacity to transport, isolate, and care for the individual is available.

The ship may need to proceed, at its own risk, to another nearby port if capacity is not available, or if warranted by the critical medical status of the suspect case.

After measures applied are considered by the port health authority to be completed satisfactorily, the ship should be allowed to continue the voyage. The measures taken should be recorded in the valid ship sanitation certificates. Both embarking and disembarking ports must be notified of contacts on board and any measures taken.

\section{Disembarkation of a Suspect and a Confirmed Case}

The ship should take the following precautions:

- Control disembarkation to avoid any contact with other persons on board;

- The patient should wear a surgical mask; and

- Personnel escorting the patient should wear suitable PPE (gloves, impermeable gown, goggles and medical mask).

The ship may proceed to its next port of call once the health authority has determined that public health measures have been completed satisfactorily in particular the measures as follows:

- Management of the suspect case or cases and close contacts;

- Completion of contact tracing forms, disembarkation of close contacts; until the termination of COVID-19 Public Health Emergency of International Concern is declared. All passengers and crew members should fill in a PLF to be kept on board for at least one month after disembarkation;

- Information in the completed PLF should be provided upon the request of health authorities to facilitate contact tracing if a confirmed case is detected after the disembarkation and after the voyage has ended;

- Information has been provided to everyone on board about the symptoms and signs of the disease and who to contact in case the relevant symptoms develop in the following 14 days; and

- Cleaning and disinfection, and disposal of infectious waste. 


\section{Cleaning, Disinfection and Waste Management}

Maintain high level cleaning and disinfection measures during ongoing on board case management.

Patients and "close contacts" cabins and quarters should be cleaned and using cleaning and disinfection protocols for infected cabins (as per Norovirus or other communicable diseases).

Environmental surfaces should be cleaned thoroughly with hot water, detergent and applying common disinfectants (e.g. sodium hypochlorite).

Once a patient has left the ship, the isolation cabin or quarters should be thoroughly cleaned and disinfected by staff using PPE who are trained to clean surfaces contaminated with infectious agents.

Laundry, food service utensils and waste from cabins of suspect cases and contacts should be treated as infectious, in accordance with procedures for handling infectious materials on board.

There should be regular communications between departments in all ships (medical, housekeeping, laundry, room service, etc) about the persons in isolation.

\section{Management of Contacts of a Suspect Case}

Port health authorities will conduct risk assessments to identify all contacts, and issue instructions to follow until laboratory results are available.

All close contacts should either complete PLFs or MDHs and remain in their cabins or at a facility ashore and follow the competent authority's instructions until laboratory results are available. The forms should contain contact details and locations where the suspect case will stay for the following 14 days.

All close contacts should be informed about the suspect case on board.

If the laboratory examination results are positive:

- All close contacts should be quarantined for 14 days; and

- The patient should disembark and be isolated ashore in accordance with the competent authority's instructions.

Quarantine measures should follow WHO guidance of considerations for quarantine of individuals in the context of COVID-19 and are also likely to include:

- Active monitoring by the port health authorities for 14 days from last exposure;

- Daily monitoring (including fever of any grade, cough or difficulty breathing);

- Avoiding social contact and travel; and

- Remaining reachable for active monitoring.

Contacts of a confirmed case should immediately self-isolate and contact health services if symptoms appear within 14 days of last exposure. If no symptoms appear, the contact is not considered at risk.

Implementation of specific precautions may be modified following risk assessment of individual cases and advice from port health authorities. 


\section{Supplies and Equipment}

Flag States regulate medical supply carriage requirements. Plentiful supplies and equipment should be available to handle an outbreak as described in the International Medical Guide for Ships 3rd edition. Reviewing the latest WHO suggested list of supplies for COVID 19, the International Maritime Health Association (IMHA) has advised that most equipment should already be on board. However, WHO also recommends other equipment that is unlikely to already be on board which IMHA suggest could be provided by a port health authority.

A table is attached at Annex $\mathbf{C}$ outlining the supplies and equipment required in a situation of COVID-19. This is based on information provided by WHO and the IMHA.

www.who.int/publications-detail/disease-commodity-package---novel-coronavirus-(ncov) 
Guidance for Ship Operators for the Protection of the Health of Seafarers

\section{Annex A Posters}

WHO and ECDC, among others, have provided advice to avoid the spread of COVID-19. To highlight their key messages and to help seafarers know how best to protect themselves and those they meet, ICS has produced the following three posters for ships.

The posters are also available to download from the ICS website at: http://www.ics-shipping.org/free-resources 


\section{COVID-19}

\section{Protect yourself and others from getting sick}

When coughing and

sneezing, cover your nose and mouth with

a tissue or a flexed elbow

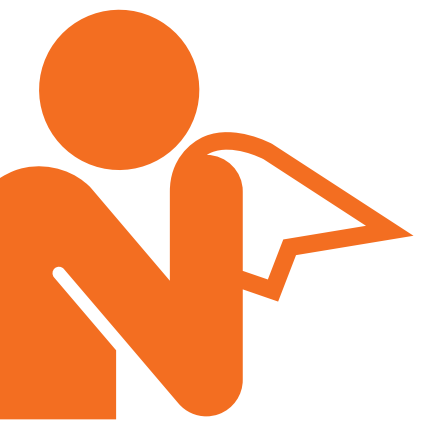

Throw the tissue into a closed bin immediately after use

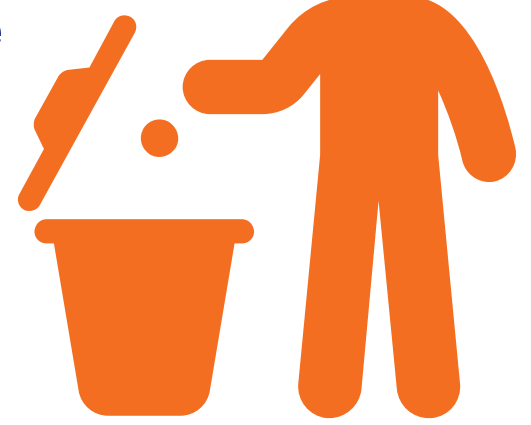

Clean your hands with an alcoholbased hand rub or with soap and hot water for at least 20 seconds:

- After coughing or sneezing

- When caring for the sick

- Before, during and after preparing food

- Before eating

- After toilet use

- When hands are visibly dirty

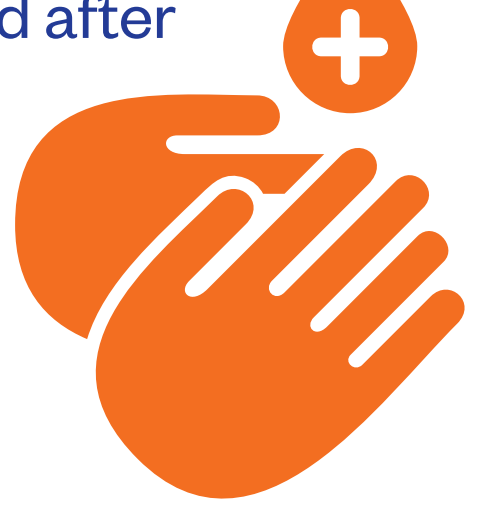

Avoid touching

eyes, nose

and mouth

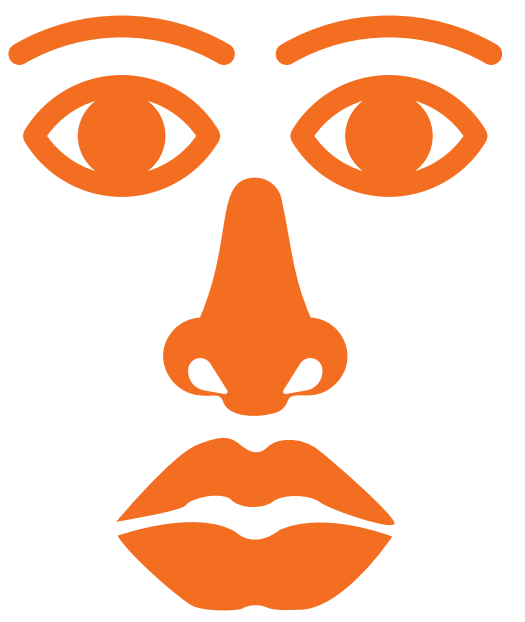




\section{COVID-19}

\section{Practise}

Food Safety

Meat products can be safely

consumed if they are

cooked thoroughly and properly handled

during food preparation

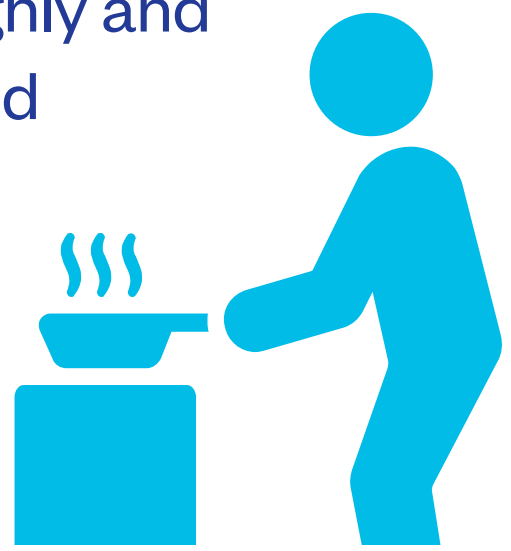

Do not eat sick or diseased animals

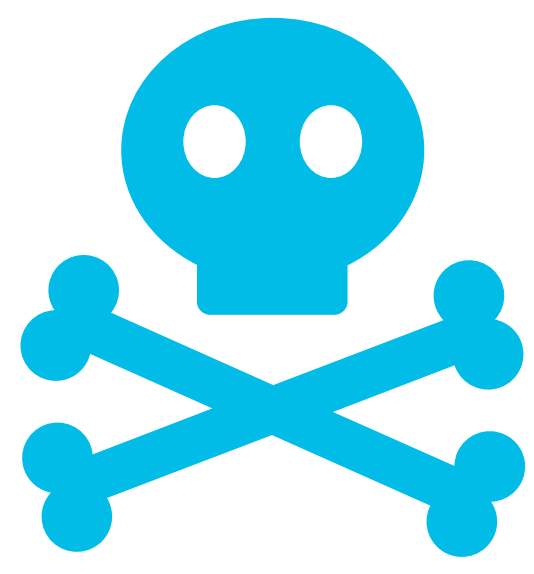

Use different chopping boards and knives for raw meat and cooked foods
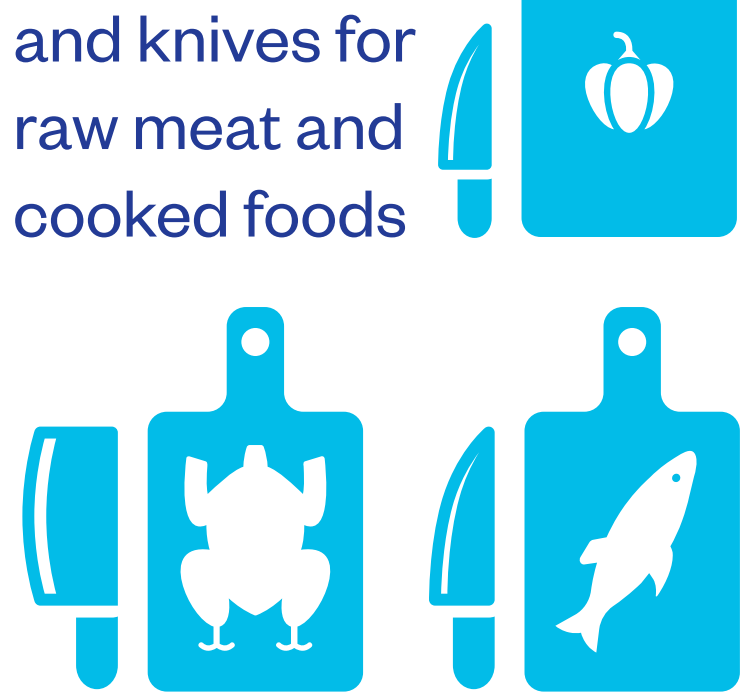

Wash your hands with soap and hot water for at least 20 seconds between handling raw and cooked food

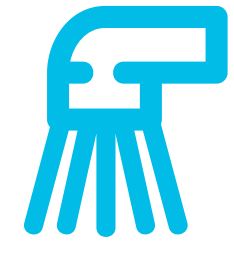




\section{COVID-19 \\ Stay healthy \\ while travelling}

Avoid these modes of travel if you have a fever or a cough

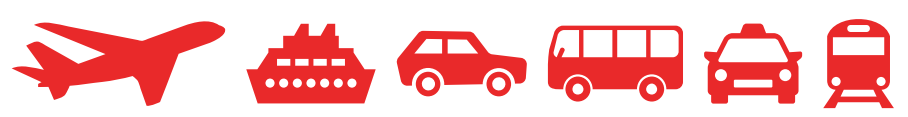

Eat only

well-cooked food

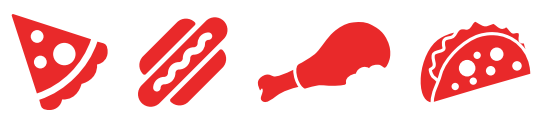

Avoid spitting

in public

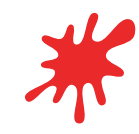

Avoid close contact and travel with

sick animals, particularly in wet markets

When coughing and sneezing, cover your mouth and nose with a tissue or flexed elbow. Throw the tissue into a closed bin immediately after use and clean your hands

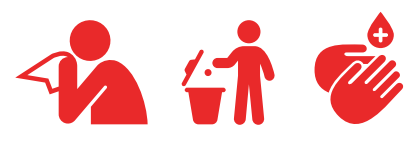

Frequently clean your hands with an alcohol-based hand rub or with soap and hot water for at least 20 seconds

Avoid touching eyes, nose and mouth

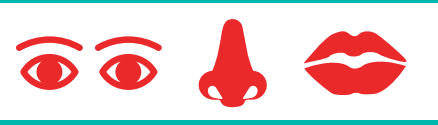

Avoid close contact with people suffering from a fever or a cough

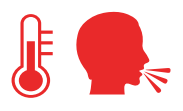

If wearing a face mask, be sure it covers your mouth and nose and do not touch it once on. Immediately discard single-use masks after each use and clean your hands after removing masks

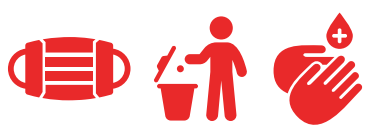

If you become sick while travelling, tell crew or ground staff

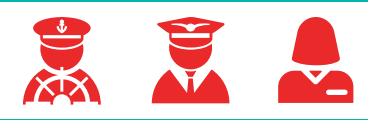

Seek medical care early if you become sick, and share your history with your health provider

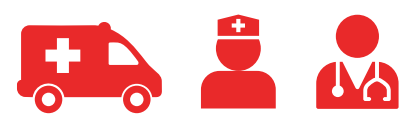




\section{Annex B \\ Sample Pre-Boarding Passenger Locator Form (PLF)}

To be completed by any adult

Name as shown in the passport or other ID:

Names of all children travelling with you under 18 years old:

Within the past 14 days, have you, or any person listed above:

- had close contact with anyone diagnosed as having Coronavirus disease (COVID-19)?

- provided direct care for COVID-19 patients, working with healthcare workers infected with novel coronavirus?

- visited or stayed in a closed environment with any patient having Coronavirus disease (COVID-19)?

- worked together in close proximity, or sharing the same classroom environment, with a COVID-19 patient?

- traveled together with COVID-19 patient in any kind of conveyance?

- lived in the same household as a COVID-19 patient? 


\section{Annex C}

\section{WHO COVID-19 Support and Logistics Supplies List, with availability advice provided by IMHA}

\begin{tabular}{|c|c|c|}
\hline Items & Comment & $\begin{array}{l}\text { Already carried } \\
\text { on board? }\end{array}$ \\
\hline \multicolumn{3}{|l|}{ CHEMICALS } \\
\hline Antibiotics & & Yes \\
\hline Chlorine & & Yes \\
\hline Fever and pain medication & & Yes \\
\hline Sodium lactate solution & & Yes \\
\hline Alcohol-based hand rub & Bottle of $100 \mathrm{ml}$ and $500 \mathrm{ml}$ & Yes \\
\hline Chlorine & NaDCC, granules, $1 \mathrm{~kg}, 65$ to $70 \%$ + dosage information & Yes \\
\hline Paracetamol & 500mg tablets & Yes \\
\hline Sodium lactate compound solution & Ringer's lactate, injection solution, w/o IV set and needle, $1000 \mathrm{ml}$ & Yes \\
\hline \multicolumn{3}{|l|}{ PPE } \\
\hline $\begin{array}{l}\text { Examination Gloves, EU MDD directive } \\
\text { 93/42/EEC Category III, EU PPE } \\
\text { Regulation 2016/425 Category III, EN 455, } \\
\text { EN 374, ANSI/ISEA 105, ASTM D6319, or } \\
\text { equivalent standards }\end{array}$ & $\begin{array}{l}\text { Nitrile, powder-free, non-sterile. Cuff length preferably reaching above the wrist } \\
\text { (e.g. minimum } 230 \mathrm{~mm} \text { total length. Sizes, S, M, L). Plentiful supplies required. }\end{array}$ & Yes \\
\hline $\begin{array}{l}\text { Surgical Gloves, EU MDD directive } \\
\text { 93/42/EEC Category III, EU PPE } \\
\text { Regulation 2016/425 Category III, EN 455, } \\
\text { EN 374, ANSI/ISEA 105, ASTM D6319, or } \\
\text { equivalent standards }\end{array}$ & $\begin{array}{l}\text { Nitrile, powder-free, single use. Gloves should have long cuffs, reaching well } \\
\text { above the wrist, ideally to mid-forearm. (Sizes 5.0-9.0) }\end{array}$ & Yes \\
\hline Gloves, cleaning & $\begin{array}{l}\text { Outer glove should have long cuffs, reaching well above the wrist, ideally to mid- } \\
\text { forearm. Cuff length preferably reach mid-forearm (e.g. minimum } 280 \mathrm{~mm} \text { total } \\
\text { length. Sizes, S, M, L), reusable, puncture resistant, FDA compliant }\end{array}$ & Yes \\
\hline Impermeable gowns single use & $\begin{array}{l}\text { Disposable, length mid-calf. - EU PPE Regulation 2016/425 and EU MDD } \\
\text { directive 93/42/EEC. FDA class I or II medical device, or equivalent, EN } 13795 \\
\text { any performance level, or AAMI PB70 all levels acceptable, or equivalent. }\end{array}$ & $\begin{array}{l}\text { Yes, but check } \\
\text { supplies are plentiful }\end{array}$ \\
\hline Scrubs - Tunic/tops & $\begin{array}{l}\text { Woven, scrubs, reusable or single use, short sleeved (tunic/tops), worn } \\
\text { underneath the coveralls or gown }\end{array}$ & $\begin{array}{l}\text { Yes, but check } \\
\text { supplies are plentiful }\end{array}$ \\
\hline Scrubs - Trouser/pants & $\begin{array}{l}\text { Woven, scrubs, reusable or single use, short sleeved (tunic/tops), worn } \\
\text { underneath the coveralls or gown }\end{array}$ & $\begin{array}{l}\text { Yes, but check } \\
\text { supplies are plentiful }\end{array}$ \\
\hline Aprons & $\begin{array}{l}\text { Heavy duty, straight apron with bib. Fabric: } 100 \% \text { polyester with PVC coating, } \\
\text { or } 100 \% \text { PVC, or } 100 \% \text { rubber, or other fluid resistant coated material, } \\
\text { Waterproof, sewn strap for neck and back fastening. Minimum basis weight: } \\
300 \mathrm{~g} / \mathrm{m} 2 \text { covering size: } 70-90 \mathrm{~cm} \text { (width) X 120-150cm (height). Reusable (if } \\
\text { decontamination arrangements exist) EN ISO } 13688 \text {, EN 14126-B and partial } \\
\text { body protection (EN } 13034 \text { or EN } 14605 \text { ), EN } 343 \text { for water and breathability or } \\
\text { equivalent. }\end{array}$ & $\begin{array}{l}\text { Yes, but check } \\
\text { supplies are plentiful }\end{array}$ \\
\hline $\begin{array}{l}\text { Goggles, protective } \\
\text { EU PPE Regulation 2016/425, } \\
\text { EN 166, ANSI/ISEA Z87.1, or equivalent }\end{array}$ & $\begin{array}{l}\text { Good seal with facial skin, flexible PVC frame to easily fit all face contours } \\
\text { with even pressure. Enclose eyes and surrounding areas. Accommodate } \\
\text { prescription glasses wearers. Clear plastic lens with fog and scratch } \\
\text { resistant treatments, Adjustable band to secure firmly and not become loose } \\
\text { during clinical activity. Indirect venting to avoid fogging. May be reused (if } \\
\text { decontamination arrangements exist) or disposable. }\end{array}$ & $\begin{array}{l}\text { Yes, but check } \\
\text { supplies are plentiful }\end{array}$ \\
\hline $\begin{array}{l}\text { Surgical masks for medics } \\
\text { ASTM F2100 minimum level } 1 \text { or } \\
\text { equivalent* }\end{array}$ & $\begin{array}{l}\text { Good breathability, clear internal and external faces. EU MDD directive 93/42/ } \\
\text { EEC Category III, or equivalent, EN } 14683 \text { Type II, IR, IIR }\end{array}$ & $\begin{array}{l}\text { Yes, but check } \\
\text { supplies are plentiful }\end{array}$ \\
\hline $\begin{array}{l}\text { Patient masks EN } 14683 \text { any type } \\
\text { including Type } I^{*}\end{array}$ & Good breathability, clear internal and external faces & $\begin{array}{l}\text { Yes, but check } \\
\text { supplies are plentiful }\end{array}$ \\
\hline Face shield (PPE) & Should be provided by Port Health Authority & Unlikely \\
\hline
\end{tabular}


Guidance for Ship Operators for the Protection of the Health of Seafarers

MEDICAL KIT

Sample medium and packaging

Disinfectants

Hand hygiene supplies

Containers

Guedel tubes

Infusion sets

Nose masks

Facial oxygen masks

Oximeter

Oxygen splitters

Safety bag and box

Commercial testing materials for samples

Fit test kit

Laryngoscope, with depressors and tubes

Oxygen concentrator

Portable ventilators

Portable ultrasound scanner

Resuscitator, child

Viral transport medium - to transport

laboratory specimens

Viral transport medium with Swab $3 \mathrm{ml}$

Bio-hazardous bag

Carbon dioxide detector

Endotracheal tube, without cuff

\begin{tabular}{|l|}
\hline Plentiful supplies required \\
\hline Plentiful supplies required \\
\hline Plentiful supplies required \\
\hline For disposable sharps and needles
\end{tabular}

Yes

Yes

Yes

\begin{tabular}{|l|l}
\hline & Yes \\
\hline & Yes
\end{tabular}

Yes

Yes

Yes

Yes

Yes

Yes

Yes

\begin{tabular}{|l|l|}
\hline Ideally a third party should take samples for suspected cases. Specific & Unlikely
\end{tabular}

materials needed to transport samples and to minimise infection

Should be provided by Port Health Authority"

\begin{tabular}{|l|l} 
Should be provided by Port Health Authority & Unlikely
\end{tabular}

Should be provided by Port Health Authority $\quad$ Unlikely

\begin{tabular}{|l|l|l}
\hline Should be provided by Port Health Authority & Unlikely
\end{tabular}

\begin{tabular}{|l|l} 
Should be provided by Port Health Authority & Unlikely
\end{tabular}

Should be provided by Port Health Authority $\quad$ Unlikely

\begin{tabular}{|l|l} 
Should be provided by Port Health Authority & Unlikely
\end{tabular}

\begin{tabular}{|l|l|l}
\hline Should be provided by Port Health Authority & Unlikely
\end{tabular}

Should be provided by Port Health Authority

Unlikely

Disposal bag for bio-hazardous waste, $30 \times 50 \mathrm{~cm}$, with "Biohazard" print,

autoclavable polypropylene. 50 or 70 micron thickness

"Disposable, colorimetric, sizes compatible with adult endotracheal tube (or

child if applicable), unlikely to be in medical cabin but usually on board a ship.

If not available ask Port Health Authority to provide along with appropriate

guidance and accessories"

Open distal end and Magill-type point with oral angle of $37.5^{\circ}$, standard

connector (ext. $\varnothing 15 \mathrm{~mm}$ ) at the proximal end to connect the tube to the

ventilation system, radio opaque mark, Murphy's eye, graduations, size: $\varnothing$

internal $3 \mathrm{~mm}$ or $3.5 \mathrm{~mm}$, material: polyvinyl chloride (PVC), disposable, sterile,

initial sterilisation method: ethylene oxide gas or gamma radiation

Endotracheal tube with cuff

Same specification as for endotracheal tube, without cuff except size: $\varnothing$ internal

$6.5 \mathrm{~mm}, 7 \mathrm{~mm}, 7.5 \mathrm{~mm}$ or $8 \mathrm{~mm}$

\section{Hand drying tissue}

Infusion giving set

$50-100 \mathrm{~m}$ roll

With air inlet and needle, sterile, single-use

Yes

Pulse oximeter

Compact portable device measures arterial blood oxygen saturation (SpO2),

heart rate and signal strength. Measuring range: SpO2 $30-100 \%$ (minimum

graduation $1 \%$ ), heart rate $20-250$ bpm (minimum graduation $1 \mathrm{bpm}$ ). Line-

powered, or extra batteries/rechargeable batteries needed at least one year. ISO 80601-2-61:2011 or equivalent

Resuscitator, adult

To ventilate adult (body weight $>30 \mathrm{~kg}$ ), with compressible self-refilling

ventilation bag, capacity: $1475-2000 \mathrm{ml}$. Resuscitator operated by hand,

ventilation with ambient air, resuscitator shall be easy to disassemble and

reassemble, to clean and disinfect, and be autoclavable. All parts must be of

high-strength, long-life materials not requiring special maintenance or storage

conditions

Sample collection triple packaging boxes

For transport as defined by the Guidance on Regulations for the Transport of

Infectious Substances 2019-2020

Safety box

Stainless steel depressor sets Miller

Stainless steel depressor sets Macintosh

Stainless steel depressor sets Macintosh

Stainless steel depressor sets Macintosh

Soap

WHO PQS E010/011

Straight $\mathrm{Nr}$ 1, length approx. $100 \mathrm{~mm}$

Curved $\mathrm{Nr}$ 2, length approx. $110 \mathrm{~mm}$

Curved $\mathrm{Nr}$ 3, length approx. $135 \mathrm{~mm}$

Curved $\mathrm{Nr} 4$, length approx. $155 \mathrm{~mm}$

Liquid (preferred), powder and bar

\section{Unlikely}


- International

_- Chamber of Shipping

Shaping the Future of Shipping

International Chamber of Shipping

38 St Mary Axe London EC3A 8BH

Telephone +442070901460

info@ics-shipping.org

www.ics-shipping.org 